\title{
O século 20 e a constituição de algumas de suas modernidades arquitetônicas: Campina Grande (PB) 1930-1950 (1)
}

Marcus Vinicius Dantas de Queiroz*

\section{Resumo}

Estuda a produção arquitetônica da cidade de Campina Grande, Paraíba, das décadas de 1930 e 1940. Analisa o caráter modernizador atribuído ao art déco, ao neocolonial, ao estilo missões e a outras manifestações em evidência nos panoramas local e nacional. Investiga os agentes, as possíveis correntes teóricas e os profissionais envolvidos com o processo. $\mathrm{O}$ artigo tem como objetivo registrar, documentar e analisar parte da ambiência cultural campinense da primeira metade do século 20. De início, o texto trata do contexto de emergência dessas arquiteturas no panorama local. Na sequência, estuda suas vinculações técnicas, espaciais e estéticas com o pensamento arquitetônico circulante na época. Para tanto, a pesquisa se alimenta de projetos originais do período, memórias, matérias de jornais e levantamento fotográfico recente.

Palavras-chave: História da arquitetura, Brasil, século 20. Arquitetura moderna, 1930-1940, Campina Grande (PB), Brasil. Produção arquitetônica.

\section{Abstract}

It deals with the architectural production of Campina Grande, Paraíba, in the 1930s and 1940s. Analyzes the modernizing element assigned to Art Deco, neo-colonial, the mission style and other events which highlight the local and national landscapes. It investigates the ways, the possible theoretical trends and the professionals involved with the process. The article aims to capture, document and analyze part of the cultural ambience from Campina Grande in the first half of the twentieth century. Initially, the text deals with the emergency context of these architectures in the local landscape. Subsequently, it studies its technical, spatial and aesthetic bounds with the architectural points of view at the time. There fore, the research gathers from the original designs of the period, memoirs, newspaper clippings and a recent photographic survey. 
Key-words: History of architecture, Brazil, twentieth century. Modern architecture, 1930-1940, Campina Grande (PB), Brazil. Production of architecture.

A origem do município de Campina Grande, interior do estado da Paraíba, é atribuída a um povoado formado no final do século 17. Elevado à categoria de vila em 1790 e à de cidade em 1864, seu espaço urbano possuía modestas proporções em princípios do século 20, limitado a 731 edificações distribuídas em volta de quatro largos e de algumas poucas ruas, becos e travessas. Em 1907, sua população era de 17.041 habitantes (incluindo zonas urbana, rural e distritos) (CÂMARA, 1947, p. 79). Embora tenha apresentado um desenvolvimento mais intenso e consistente só a partir da segunda metade do século 19 , foi reproduzindo os procedimentos de construção de muitos núcleos coloniais brasileiros que a cidade cresceu até as primeiras décadas do século 20: ruas muitas vezes sinuosas, desalinhadas e que acompanhavam a topografia do sítio, becos reduzidos, largos abertos diante dos principais edifícios de uso público, construções majoritariamente térreas, assentadas sobre lotes estreitos e compridos, só deixando como espaço livre uma porção de terreno nos fundos.

Em 1907, a instalação do terminal da ferrovia inglesa Great Western Brasil Railway dinamizou a economia local. Dentre outros produtos, isso viabilizou o rápido escoamento da produção algodoeira do interior paraibano e de parte dos estados vizinhos para os portos da Paraíba e, principalmente, de Pernambuco, que, daí, era destinada para os mercados nacional e internacional. Tal fato gerou um vertiginoso incremento populacional e, consequentemente, urbano. Em 1940, impressionava a expansão física ocorrida em pouco mais de trinta anos. A sua população saltou de 17.041 habitantes, em 1907, para 126.443 habitantes, em 1940. No mesmo intervalo de tempo, o número de edificações urbanas campinenses pulou de 731 para 8.662 prédios, e já eram 17.240 em 1954. Em 1950, Campina Grande já era habitada por 173.206 pessoas $(2)$.

Desse modo, o trem foi um dos propulsores e símbolos da modernidade campinense. Contudo, concordando com Aranha (2001 e 2005), a ideia de moderno 
para as experiências urbanas brasileiras do início dos novecentos se definiu menos pelos ritmos sociais frenéticos, como os verificados em Londres e Paris no século 19, e mais pela absorção de símbolos que se tornaram tradutores dessa modernidade, ou, como diziam os discursos da época, da civilidade. Na ausência de modernizações econômica, política e social mais profundas e que representassem maior ruptura em relação ao passado oitocentista (escravista, rural, agrárioexportador e aristocrático), em muitos casos o conceito de pessoa ou lugar civilizado passou a ser associado ao acesso aos avanços da tecnologia, da ciência e de tudo o que isso envolvia em termos de hábitos, consumos e imagens, de si e da cidade. O conceito de modernização estava intimamente ligado à ideia de progresso, de ir adiante. A palavra moderno expressava a aceitação de que a sociedade poderia melhorar e se superar, sempre em relação a outro estado anterior considerado de menor evolução. Supunha, ainda, certa desvalorização do anterior e o reconhecimento de que era possível e bom mudar e melhorar (CAPEL, 2006, p. 9).

Nesse contexto, ganharam vulto ações de modernização da estrutura urbana de Campina Grande, pautadas nos ideais de higiene, circulação e embelezamento. Atreladas a um panorama maior de modernização das cidades brasileiras, intensificado no final do século 19, as iniciativas tiveram como intuito resolver uma série de questões surgidas ou agravadas com o rápido crescimento do município a partir do dinamismo econômico verificado em princípios do século 20: adensamento demográfico, insalubridade de ruas e moradias, problemas de abastecimento de água e coleta dos esgotos, mistura de usos e funções, reprodução de habitações precárias, vias incompatíveis com as novas velocidades e necessidades de circulação dos transportes mecanizados.

Assim, as décadas de 1930 e 1940 assistiram a grandes transformações na paisagem urbana campinense. Ruas foram alinhadas, reticuladas, drenadas, pavimentadas e arborizadas; avenidas foram abertas, usos e classes sociais separados, foram instalados serviços mecanizados de abastecimento de água e coleta de esgoto. O antigo conjunto arquitetônico das áreas centrais foi, em boa parte, colocado abaixo para o surgimento de novos edifícios, os recentes subúrbios abertos trouxeram formas aburguesadas de morar. $\mathrm{Na}$ arquitetura, as práticas nacionais do momento elaboraram os edifícios surgidos em meio a esse processo. 
Desde o que se convencionou chamar de art déco até a vertente nacionalista do neocolonial, as novas construções vieram imbuídas de todas as indefinições e limitações do que seria a modernização da arquitetura brasileira naquelas primeiras décadas dos novecentos.

Diante do exposto, o artigo ora apresentado busca, através do estudo de caso da cidade de Campina Grande, compreender uma parcela significativa da produção arquitetônica brasileira das primeiras décadas do século 20 , com ênfase nos anos 1930 e 1940. De início, tratamos do contexto de emergência dessas arquiteturas no panorama local. Na sequência, o texto estuda suas vinculações técnicas, espaciais e estéticas com o pensamento arquitetônico circulante na época. Para tanto, a pesquisa se mune de projetos originais do período, memórias, matérias de jornais e levantamento fotográfico recente. Esse conjunto de informações foi sistematizado, analisado e compreendido via aporte teórico fornecido pela literatura existente sobre o tema, que contemplou situações e conceitos de nosso interesse difundidos no Brasil e em outros países, nunca perdendo de vista as peculiaridades locais.

\title{
Estilo moderno, feição moderna, tipo moderno
}

\begin{abstract}
Sabemos que o culto à 'Deusa Carne e ao Deus Milhão' absorve uma percentagem bem elevada das atividades humanas [...]. Daí a razão por que a cidade [de Campina Grande] é tão rica de iniciativas econômico-materiais e tão pobre das que se dirigem às cousas do espírito [...]. Parece incrível que isto aconteça numa cidade tão florescente e dotada duma beleza arquitetônica sem igual no Estado (CÂMARA, 1950).
\end{abstract}

Denunciando a corrida materialista, reclamando a falta de iniciativas de cunho cultural, que investissem na educação e nas coisas do espírito, Epaminondas Câmara distancia-se das opiniões por ele emitidas, em seus livros de 1943 e 1947, acerca da arquitetura da cidade do final dos oitocentos e do começo dos novecentos. De uma arquitetura considerada pobre e acanhada, que envergonhava os campinenses diante dos demais paraibanos, para uma "beleza arquitetônica sem igual no Estado". Com novos materiais, técnicas construtivas, imposições legais, demandas e padrões estéticos, urbanísticos e comportamentais, com a formação de um quadro local de técnicos, empresas e profissionais vinculados à construção civil 
e com outras escalas frente ao dinamismo econômico do município, boa parte da arquitetura constituída ao longo das décadas de 1930 e 1940 contribuiu para a renovação da paisagem urbana de Campina Grande, tornando-a compatível com as demais ações reformistas, deixando-a com ares mais civilizados, como diziam.

A busca por uma arquitetura que caminhasse junto com os avanços, as dimensões e as necessidades do homem e da cidade modernos, que compreendesse e respondesse a hábitos, lógicas, dinâmicas e ritmos inéditos, representou momento de indefinição, de dúvida e de ruptura em relação à produção do espaço construído em voga até então. Vários caminhos foram colocados, imbuídos ou destituídos de ideologias mais profundas, das arquiteturas do final do século 19 (arquitetura do ferro, Escola de Chicago, art nouveau e o próprio ecletismo), caminhando pelas vanguardas europeias do começo do século 20 , até as experiências estéticas do que se convencionou chamar de art déco. Nesse embate, desejava-se alguma modernidade, mesmo que apenas aparente. A casa, o escritório, o comércio; os ambientes do morar, do trabalhar e do se divertir, ainda que conservando antigas práticas espaciais e técnico-construtivas, deveriam espelhar em suas fachadas e para o espaço público de ruas, praças e avenidas o espírito de renovação, de modernização da época. Suas ressonâncias foram sentidas nos mais diversos contextos, debatidas, absorvidas e interpretadas das mais variadas formas. Assim como a maneira de se vestir, o jeito de se comportar e o lazer escolhido para as horas livres, queria-se que a arquitetura estampasse uma imagem de modernidade, não raro referenciada e dissipada pelos apelos da recente indústria publicitária e pelos inéditos meios de comunicação de massa.

As expressões estilo moderno, feição moderna e tipo moderno, que dão título a essa seção, foram escritas em projetos apresentados à Diretoria de Obras de Campina Grande ao longo do nosso período de estudo. Por si só, já são indicativos de uma arquitetura que se queria outra, nova. Não se referiam a uma linguagem própria, definida. De maneira geral, denominavam as mais diversas manifestações que representassem alguma inovação/modernização no cenário local frente à simplicidade do seu aspecto construtivo no começo dos anos 1930. São tão diversas e híbridas que chegam a nos comprometer e até a nos confundir em qualquer tentativa de classificação mais rigorosa. Poderiam se referenciar em expressões que 
iam desde o que hoje nós conhecemos e denominamos como art déco, passando por resquícios de um ecletismo historicista em fim de linha, até as chamadas manifestações românticas, ligados à estética do pitoresco e aos movimentos nacionalistas das primeiras décadas do século 20, como o neocolonial ou o missões.

Esse convívio entre linguagens distintas, presentes de maneira isolada ou misturada em uma só edificação, fazia coro com o cenário da arquitetura brasileira dos finais do século 19 e começo do 20. Aspectos como a influência das referências estrangeiras (via projetistas, mão-de-obra ou clientes - principalmente europeus), a importação de materiais industrializados, o desenvolvimento das técnicas construtivas, as preocupações higienistas, a adoção de novas formas de morar, o aparecimento de novos programas em escalas inéditas, a perseguição da funcionalidade, da eficiência e da economia pelo mercado da construção civil e por obras governamentais, a acelerada urbanização do país e a busca por uma arquitetura tradicional brasileira, que fizesse jus aos inflamados discursos nacionalistas do começo do século passado, forjaram tal quadro de heterogeneidade arquitetônica, muitas vezes de difícil distinção (3). Parte dessas arquiteturas refletiu o espírito de modernização do país das décadas de 1920, 1930 e 1940, em consonância com a gestação e com a emergência do movimento de arquitetura moderna brasileira.

Leituras comumente associam as reformas urbanas de Campina Grande ao surgimento do art déco em âmbito local, tomando-o como linguagem única e exclusiva desse processo. Seria o fruto dos esforços da municipalidade na tentativa de padronizar as construções das áreas centrais atingidas pelas reformas, algo como uma arquitetura oficial, ao gosto do então prefeito Vergniaud Wanderley. É certo que, do ponto de vista quantitativo, o art déco foi a manifestação predominante. Talvez tenha sido majoritária não só em Campina Grande, mas em todas as cidades brasileiras com certo incremento construtivo na época, como na recém criada capital do Estado de Goiás, Goiânia (4). Isso sem falar na sua larga difusão pelos demais países da América Latina (5). Porém, não podemos limitar o processo de modernização campinense apenas a sua região central e ao art déco, esquecendo do que estava sendo feito nos recentes subúrbios residenciais. Ademais, mesmo nos logradouros centrais mais importantes, as reconstruções não 
chegaram a conformar conjuntos homogêneos, com gabaritos e linhas arquitetônicas rigidamente controlados. Embora conservando certa unidade em determinados trechos, os sobrados levantados em ruas como a Maciel Pinheiro ou a Venâncio Neiva comumente ostentavam linguagens híbridas ou referências formais distintas (Figura 01). 

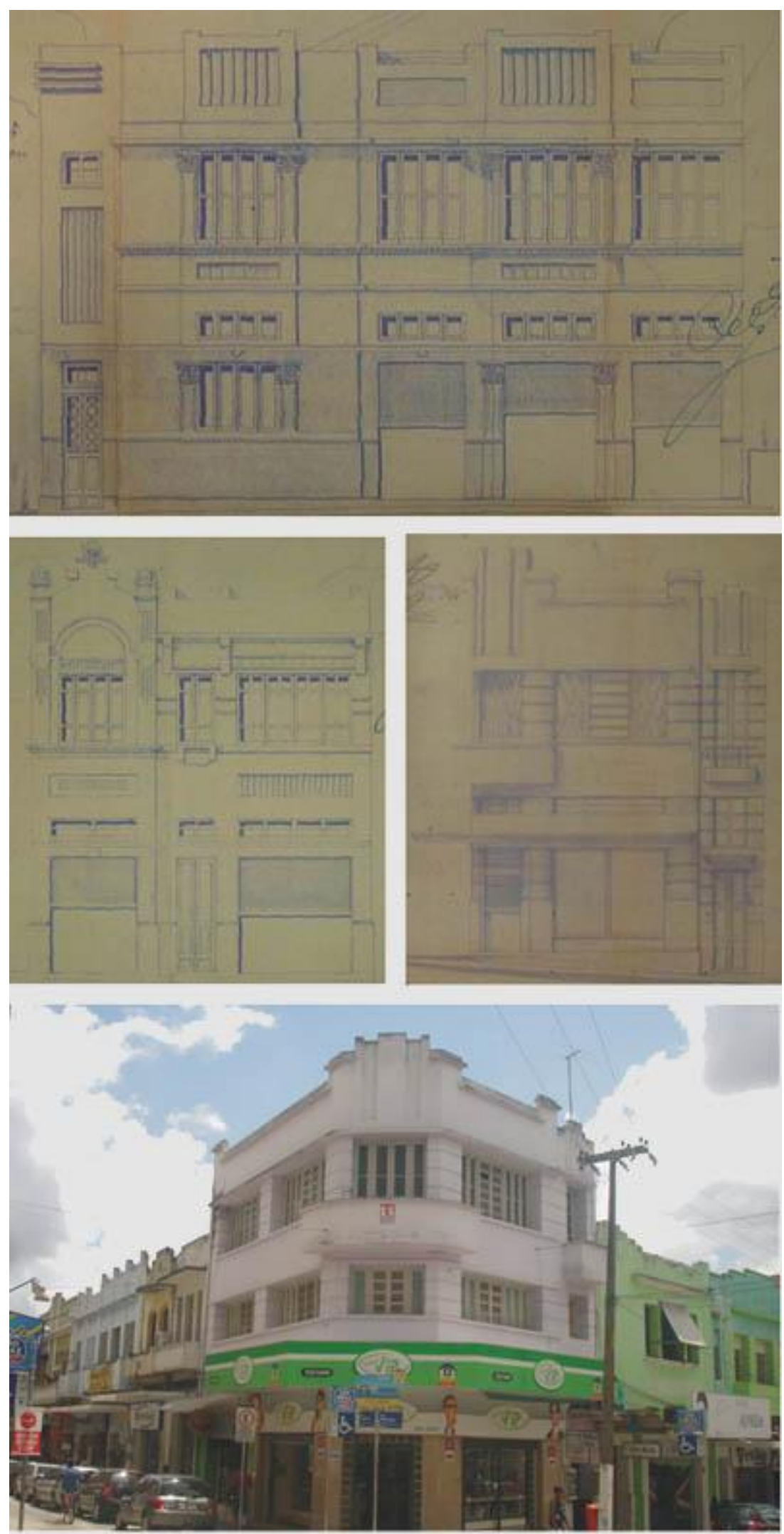

Figura 01: Eclético ou art déco? Uso de referências formais distintas em sobrados da regiz̃o central. Acima, sobrado para João de Matos. Rua Venâncio Neiva, 1944. Projeto do arquiteto licenciado Josué Barbosa. Ao centro, à esquerda, sobrado para Júlio Costa. Rua Venáncio Neiva, 1944. Projeto do arquiteto licenciado Josué Barbosa. Ao centro, à direita, e abaixo, sobrado para Gil Braz de Figueredo. Esquina entre as ruas Venáncio Neiva e Monsenhor Sales, 1945. Projeto do arquiteto licenciado Josué Barbosa. Fontes: ARQUIVO PÚBLICO MUNICIPAL DE CAMPINA GRANDE. Foto do autor. 
$\mathrm{Na}$ verdade, as primeiras ressonâncias do art déco, do neocolonial e das demais linguagens consideradas de feição moderna pelos fiscais da Diretoria de Obras de Campina Grande foram sentidas em momento anterior à intensificação das medidas reformistas a partir de meados da década de 1930, em consonância com o aumento do número de construções e com o estabelecimento de arquitetos, desenhistas e engenheiros na cidade. Suas aparições inaugurais foram resultados de iniciativas particulares, de projetos feitos por técnicos, pedreiros ou mestres-de-obras. Em 1933, grande parte dos projetos apresentados à Prefeitura já seguia as referências art déco. Nesse mesmo ano e caminhando por essa mesma linguagem formal, o Governo Federal construiu a nova sede dos Correios e Telégrafos, onde hoje fica a Praça da Bandeira (Figura 02) (6).
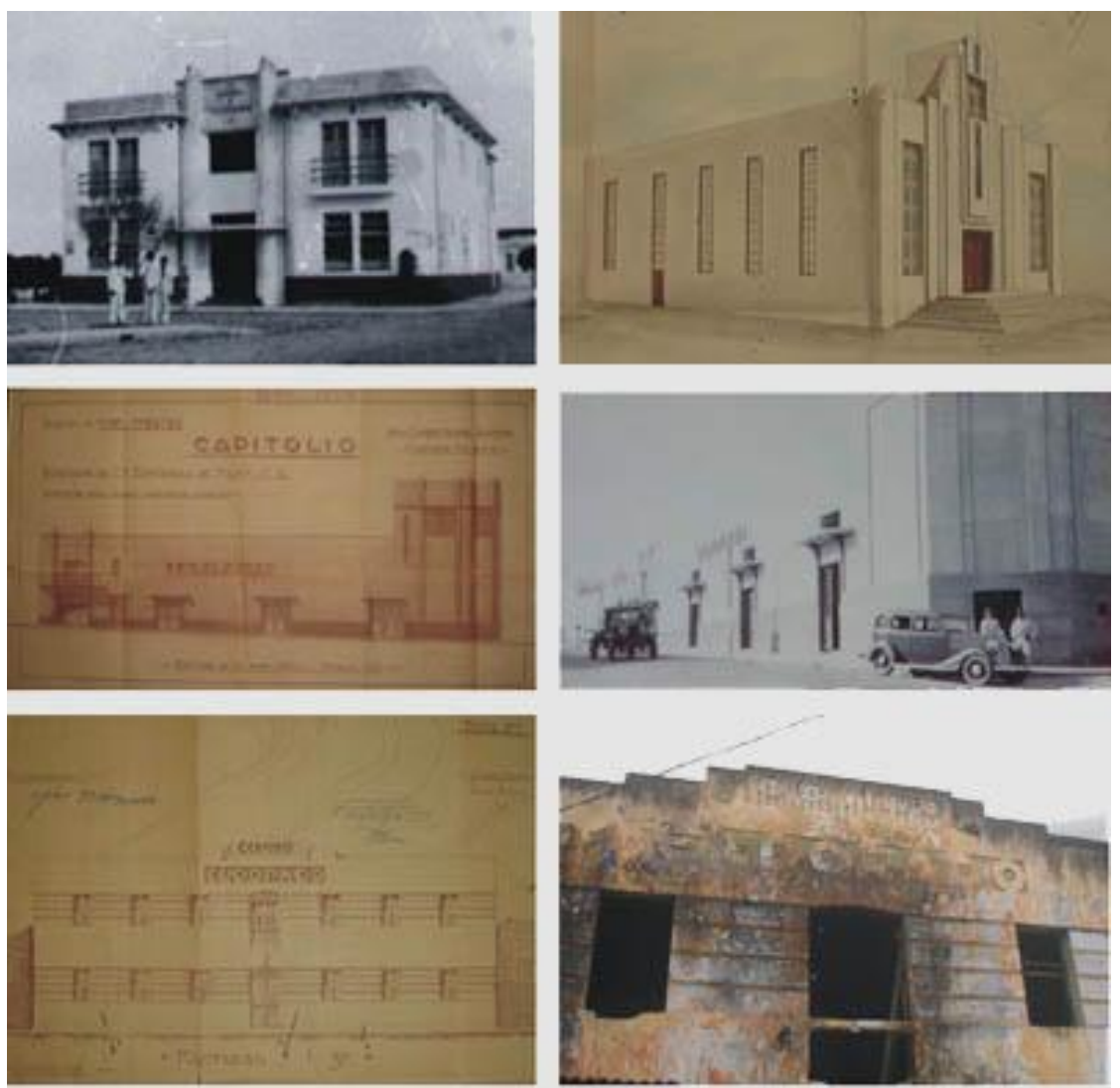

Figura 02: Acima, à esquerda, edificio dos Correios e Telégrafos, 1933. Acima, à direita, Igreja Presbiteriana, 1934. Projeto de F. Bolivar. Ao centro, Cine-Theatro Capitólio, 1934. Projeto do arquiteto licenciado Isaac Soares. Abaixo, Cassino Eldorado, 1937. Projeto do arquiteto licenciado Isaac Soares. Um dos locais de trabalho de Jackson do Pandeiro nos anos em que morou em Campina Grande. A situação atual é de abandono. Fontes: Arquivo pessoal Severino Cabral Filho. Arquivo Público Municipal de Campina Grande. Museu Histórico de Campina Grande. Foto do autor. 
O dinamismo econômico local, aliado à exigência da municipalidade para que as construções e reformas das áreas urbana e suburbana fossem planejadas por profissionais vinculados aos Conselhos Regionais de Engenharia e Arquitetura, como determinou a Lei №. 23.569 de 11 de dezembro de 1933, abriu mercado para a fixação de arquitetos, desenhistas e engenheiros na cidade. Isso representou não apenas rupturas nas soluções técnicas, espaciais e construtivas no comum das edificações de então, mas também colaborou para o desenvolvimento dessas novas linguagens estético-formais. Embora arquitetos tenham atuado em momento anterior na cidade, como o italiano Hermenegildo di Lascio (projeto do Grupo Escolar Solon de Lucena, inaugurado em 1924), foi em 1933 que se estabeleceu o primeiro escritório de arquitetura em Campina Grande, o do arquiteto licenciado Isaac Soares (7). Na década seguinte, foi a vez do também arquiteto licenciado Josué Barbosa (8) fazer o mesmo. Tais escritórios foram responsáveis por grande parte da produção local dos anos 1930 e 1940, estendendo-se com menor vigor pelos 1950 e 1960, atuando nas áreas de projeto de edificação e de interiores e na construção civil.

Paralelamente, engenheiros civis e desenhistas possuíam licença para projetar no município, como foi o caso de Ubyrajara Pompilio (desenhista), Cícero José de Sousa (desenhista), Zacarias Carvalho (desenhista), F. Bolivar (desenhista), Antônio Henriques (desenhista), Marina Carvalho (desenhista), Antônio Maria de Figueiredo Junior (engenheiro), Giovanni Gioia (engenheiro, italiano radicado em Campina Grande), Josias Coelho Queiroz (engenheiro), J. B. Toni (engenheiro), Austro de França Costa (engenheiro) (9) e Saturnino de Brito Filho, cujo escritório foi responsável pelo projeto e pela execução dos edifícios do sistema de saneamento da cidade. Ao mesmo tempo, arquitetos de outros lugares foram solicitados para trabalhar em Campina Grande, como Georges Munier (francês radicado em Recife), Heitor Maia Filho (Recife), Brandão Magalhães (Recife), Fernando Oliveira e Clodoaldo Gouvêa (capixaba radicado em João Pessoa, um dos principais personagens da modernização arquitetônica da capital paraibana nos anos 1930 (10)).

A procedência da formação da maioria desses profissionais ainda requer uma pesquisa mais específica. Sabemos, apenas, que tanto Oliveira como Gouvêa passaram pela Escola Nacional de Belas Artes do Rio de Janeiro (ENBA). Até 1945, 
quando o ensino de arquitetura começou a ser disseminado pelo país, a ENBA era a principal escola de formação de arquitetos do Brasil, cuja origem vinha da Academia de Belas-Artes, fundada na então Capital Federal, em 1826, com a pretensão de implantar o ensino artístico de alto nível no Império (SEGAWA, 2002, p. 130).

Assim, tal quadro profissional instaurado ou em circulação por Campina Grande foi responsável pela elaboração do que seria essa desejada arquitetura de estilo, feição ou tipo moderno. Na busca por suas afirmações, arquitetos, engenheiros e desenhistas projetavam de tudo ao mesmo tempo, de acordo com a vontade e com as necessidades dos clientes e desvinculados de alguma possível corrente ideológica, como os discursos nacionalistas que guiaram a essência das concepções neocoloniais ou a vertente marajoara do déco. O interessante também é observar a evolução da obra de alguns desses profissionais ao longo do tempo. Nos anos 1930 e 1940, o trabalho do arquiteto Isaac Soares, por exemplo, seguia majoritariamente pelos caminhos do art déco e das manifestações românticas. Já em finais dos 1950 e início dos 1960, parte das suas concepções passou a se filiar ao movimento de arquitetura moderna, demonstrando a adoção de outra (ou de mais uma) prática projetual. Eram reflexos, em terras campinenses, de discussões e realizações arquitetônicas em circulação pelo país. Porém, voltemos aos anos 1930 e 1940 e tentemos entender os significados e as traduções dessas linguagens que foram colocadas como modernas até então.

\section{O art déco em Campina Grande}

O art déco representou um caminho mais curto, urgente, na busca por uma imagem de modernidade, sem grandes rupturas com as estruturas físicas e sociais do passado. Na arquitetura, o seu desenvolvimento deu origem a uma linguagem estética que tentou espelhar o frescor, a higiene, os ritmos frenéticos, a lógica produtiva, o progresso, o apelo consumista e os avanços técnico-científicos do mundo moderno. O art déco foi lançado formalmente ao mundo na Exposition Internacionalle des Arts Décoratives et Industrielles Modernes de Paris, em 1925. Na ocasião, perseguia-se uma estética que dialogasse com a sociedade industrial nascente, que pudesse ser aplicada aos mais diversos objetos do cotidiano, da casa aos móveis, dos eletrodomésticos a peças do vestuário. Porém, era um diálogo que forjava uma modernidade de caráter eminentemente decorativo, referenciada em 
fontes tão diversas e distintas entre si como Compagnie des Arts Français e a Bauhaus (11), não deixando de flertar com o classicismo e o ecletismo então correntes. Como afirma Pinheiro (2008, p. 112), o déco tinha uma atitude descompromissada quanto a princípios teóricos gerais, especialmente na relação forma-função, algo tão característico da arquitetura moderna.

Com origem na Europa, o art déco rapidamente se expandiu para as Américas do Norte e do Sul, onde se difundiu principalmente via novos meios de comunicação de massa, como o cinema (estética do filme Metropolis, de Fritz Lang), as revistas ilustradas, o rádio e a propaganda (12). O termo art déco só foi outorgado em 1966, por ocasião da exposição revisionista Les Années 25, realizada no Museu de Artes Decorativas de Paris em comemoração à exposição de 1925 (CAMPOS, 1996, p. 17). Sob esse rótulo, tentava-se reabilitar uma produção do entreguerras de móveis, objetos e bibelôs com certas especificidades formais e que tinha sido esquecida pela história, integrando-a de maneira mais ampla a correntes artísticas tão diversas como a Bauhaus, o De Stijl ou o Esprit Nouveau (BRESLER, 1997, p. 11). A denominação também foi estendida à arquitetura. Assim, nos anos 1920, 1930 ou 1940, nenhum artista, design ou arquiteto definia a sua obra como art déco, muito menos clientes e administradores públicos a conheciam dessa forma. Em tais décadas, a corrente estética ganhou vários batismos no Brasil e no exterior, ficando conhecida, dentre outros nomes, como modernistic, jazz modern style, zigzag modern, style 1925, Paris 25, streamlined modern, futurismo, cubismo (13) ou estilo, feição e tipo moderno, como foi o caso de Campina Grande.

Mesmo reconhecendo a existência de elementos comuns em suas diversas vertentes, a ausência de uma desejável homogeneidade estilística, aliada às várias fontes das quais se alimentou em busca de uma estética moderna, tornaram o art déco extremamente híbrido (CAMPOS, 2003, p. 40-41). Para Pinheiro (1997, p. 205), "apesar de apresentar tantas e tão variadas fontes de influência decorativa, o art déco é sempre facilmente identificável".

Isto porque a concepção espacial geral é sempre calcada na rigorosa observância dos preceitos compositivos da École des Beaux Arts de Paris: composição de fora para dentro, simetria absoluta em torno de um ou mais eixos, etc. Além disso, o art déco também se 
caracteriza por utilizar invariavelmente certos mecanismos de uniformização dos elementos ornamentais - tais como a estilização e geometrização -, que têm como resultado a homogeneização das suas várias fontes de influência decorativa. Esse procedimento, que deriva dos movimentos artísticos de vanguarda e sua tendência à abstração, é em grande parte responsável pelo aspecto moderno do art déco - que, entretanto, não vai muito além das aparências externas. (PINHEIRO, 1997, p. 205-206).

Conde e Almada (2000, p. 14) ainda acrescentam como características que permearam a produção art déco: no plano horizontal, composição simétrica/axial, com acesso centralizado ou valorizando a esquina; no plano vertical, composição tripartida em base, corpo e coroamento escalonado, predominância de cheios sobre vazios, articulação de volumes geometrizados e simplificados (varandas semiembutidas) ou sucessão de superfícies curvas (aerodinamismo), presença do ornamento, linguagem formal tendente à abstração, composição com planos verticais e horizontais fortemente definidos e contrastados, valorização dos acessos e portarias, iluminação feérica e cenográfica (intenção manifesta desde as perspectivas que acompanhavam os projetos).

Em Campina Grande, como no resto do país, as formas escalonadas e aerodinâmicas foram o comum da produção, associadas a praticamente todos os programas da época, das residências às igrejas. Cinemas, clubes esportivos e recreativos, cabarés, postos de gasolina e demais programas modernos e que precisavam atrair público quase sempre se vestiram dessa linguagem estética, em busca de uma imagem de civilidade que refletisse os novos tempos e a recente prosperidade econômica do município (Figura 02). A construção de um posto de serviços para automóveis em forma de avião, em pleno centro da cidade, foi um episódio emblemático desse gesto de tomar para si signos que pudessem comunicar alguma aparência de modernidade. Afinal de contas, o que seria mais moderno do que automóveis, aviões e velocidade?

No panorama campinense, $\mathrm{o}$ art déco, como $\mathrm{o}$ neocolonial $\mathrm{e}$ as demais manifestações em evidência durante o nosso período de estudo, surgiu com a difusão de uma série de inovações que em outros lugares do país vieram associadas ao ecletismo, desde finais dos oitocentos. A ruptura da implantação colonial (fruto das exigências higienistas que afastaram os edifícios dos limites do 
lote), os arranjos mais complexos de plantas e telhados, a incorporação de maiores avanços técnico-construtivos advindos com a revolução industrial e a introdução de toda uma tecnologia doméstica a partir da instalação das redes mecanizadas de abastecimento de água e coleta dos esgotos reforçaram o caráter de modernidade dessas arquiteturas em âmbito local.

Em 18 de março de 1936, o jornal oficial do Estado, A União, trouxe algumas incursões acerca da decoração marajoara, temática que buscava, nas cerâmicas indígenas encontradas na llha do Marajó (Pará), expressões próprias para a cultura brasileira (14). Na arquitetura, a aplicação estilizada, geometrizada e simplificada de tais formas deu origem a uma vertente art déco de cunho nacionalista, com ênfase decorativa (15). Apesar da circulação de tais ideias via imprensa paraibana, essa não foi uma temática comum do art déco campinense. Esse primou pela economia de ornamentos, pelo tratamento superficial das fachadas e pela simplicidade construtiva. $\mathrm{O}$ uso de listras, disposição simétrica, elementos geométricos em baixo e alto relevo, esquinas e cantos arredondados, letreiros incorporados à composição geral do edifício, sacadas, marquises sobre janelas e acessos, planos escalonados em platibandas e marcando a verticalidade dos prédios foram os recursos mais utilizados na produção local, tanto por arquitetos, desenhistas e engenheiros quanto por pedreiros e mestres-de-obras em expressões mais populares e de baixo custo.

As constantes composições de linhas verticais, mesmo em edificações térreas, procuravam uma compatibilização com os novos modelos de imagem urbana exigidos pelos gabaritos de altura, sempre em busca do crescimento para cima e do maior aproveitamento do lote (figura 03). Não é à toa que os arranha-céus estadunidenses (muitos de estética art déco), associados a ruas com intenso fluxo de veículos, passaram a representar o ideal de cidade moderna a ser perseguido, com reflexos até os dias de hoje nas cidades brasileiras. Já o uso quase generalizado de marquises de concreto armado sobre as calçadas dos edifícios comerciais construídos ou reconstruídos na região central é um indicativo da sua possível obrigatoriedade, tal como fazia o Regulamento de Construção do Município de João Pessoa de 1938. Sua utilização sobre os passeios tinha a função de proteger um espaço público que agora ganhava outra dinâmica, a do consumo. Desse modo, o sol e a chuva não mais atrapalhariam o deambular das pessoas em 
frente às novas vitrines e lojas abertas. $O$ uso desses elementos criou planos contínuos de marquises nos logradouros comerciais do centro de Campina Grande, enfatizando a regularidade e as perspectivas lineares e infinitas de ruas como a Maciel Pinheiro e a Venâncio Neiva (figura 04).
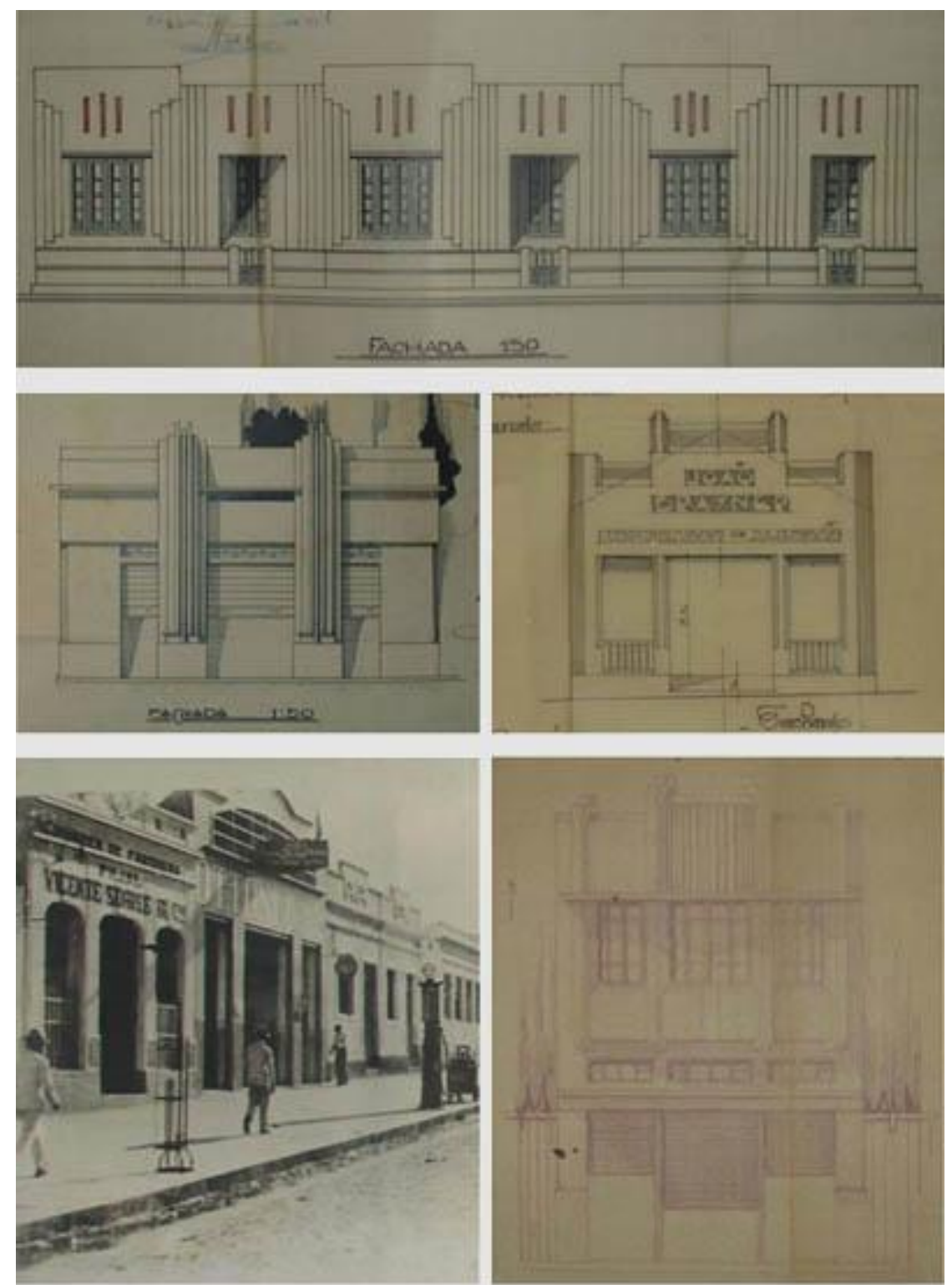

Figura 03: Predominância de linhas verticais. Acima, projeto para habitaçōes unifamiliares geminadas. Travessa do Chafariz, 1936. Desenhista Marina Carvalho. Ao centro, à esquerda, projeto para armazém, 1936. Desenhista António Henriques. Ao centro, à direita, projeto para armazém de algodão. Propriedade de João Brayer. Rua da República, sem data. Projeto do arquiteto Georges Munier. Abaixo, rua João Pessoa. Á esquerda, sequência de portas estreitas, 1929. A direita, portas de aço ocupando toda a frente do pavimento térreo da edificaçð̄o. Projeto de sobrado para Jemil Asfora \& Cia, 1946. Fontes: Arquivo Público Municipal de Campina Grande. Museu Histórico de Campina Grande. 

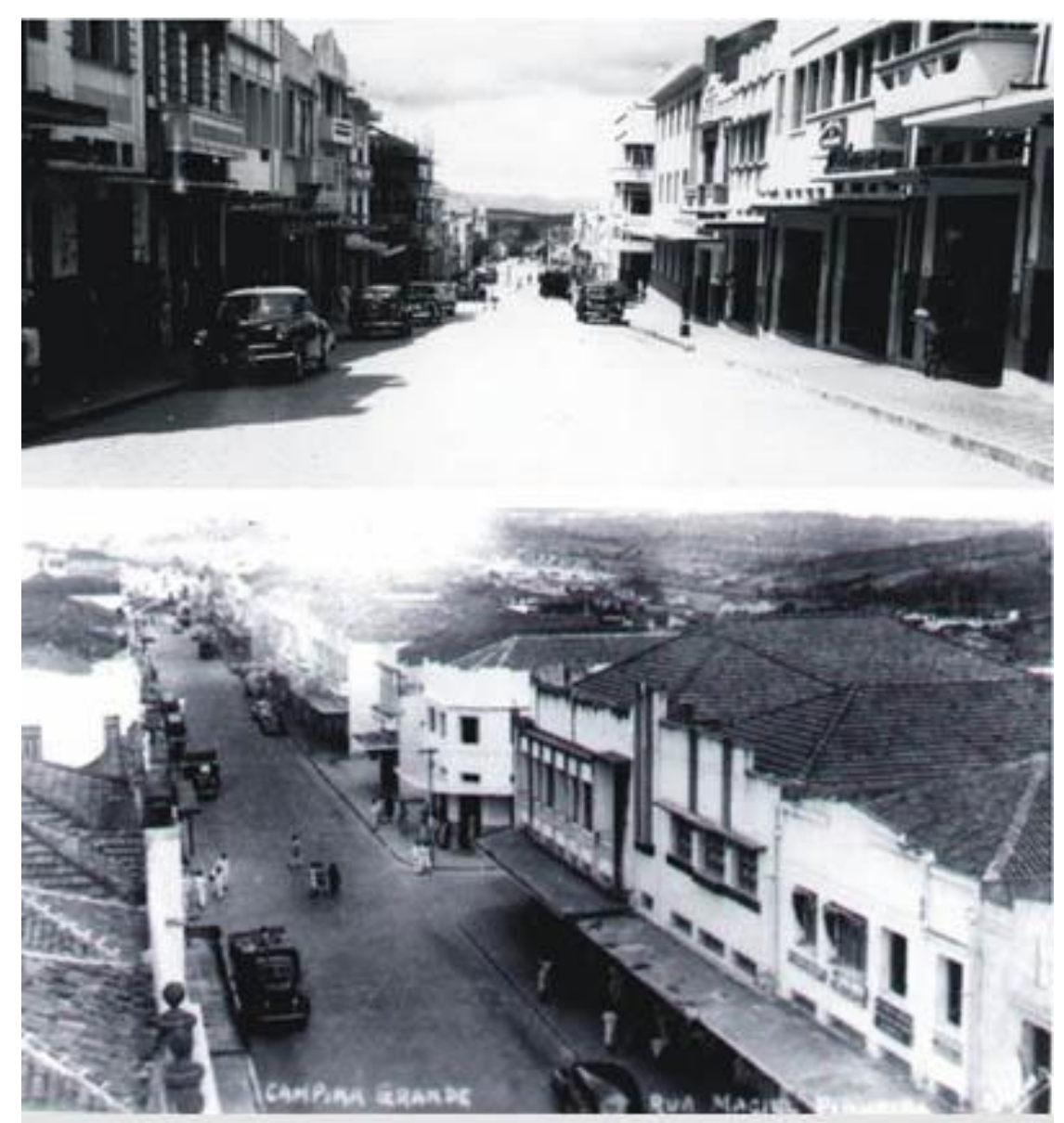

Figura 04: Acima, rua Venâncio Neiva, década de 1940. Abaixo, rua Maciel Pinheiro, década de 1950 [?]. Fontes: Arquivo Humberto Nóbrega/Unipê (Acervo pessoal Francisco Sales Trajano Filho). Museu Histórico de Campina Grande.

Parte dos resultados técnico e estético do art déco campinense também se vinculou ao surgimento e à difusão das estruturas de concreto armado na cidade. Como afirmou Câmara (1947, p. 136) em 1940, "surgiu o gosto pelo cimento armado" no município. Marquises em balanço, edifícios com paredes mais leves e vãos maiores em ambientes e esquadrias foram conquistados com o uso da técnica. Os antigos armazéns e mercearias, com suas sequências de portas estreitas de madeira (geralmente de duas folhas), quase sempre deram lugar a planos únicos de portas de aço (de enrolar), as quais passaram a ocupar boa parte das testadas das edificações comerciais (figura 03). Através desse maior contato estabelecido entre interior e exterior, entre espaços privado e público, as lojas ficaram mais expostas para o consumo dos passantes.

Contudo, as técnicas tradicionais de construção não foram abandonadas. As estruturas de concreto armado foram mais utilizadas nos grandes edifícios públicos 
e nos sobrados levantados nas ruas centrais, muitas vezes associadas a paredes portantes de tijolos nesse último caso (figura 05). As demais edificações continuaram executando um art déco que fez uso de métodos convencionais de construção, de mais fácil, barata e sabida execução por pedreiros e mestres-deobras. Como afirma Teixeira (2003), a racionalização ou redução geométrica, a estilização dos detalhes construtivos, somada a uma tecnologia tradicional (paredes portantes, tímidas estruturas de concreto armado), possibilitou a expansão do art déco nos canteiros de obra mundo afora.
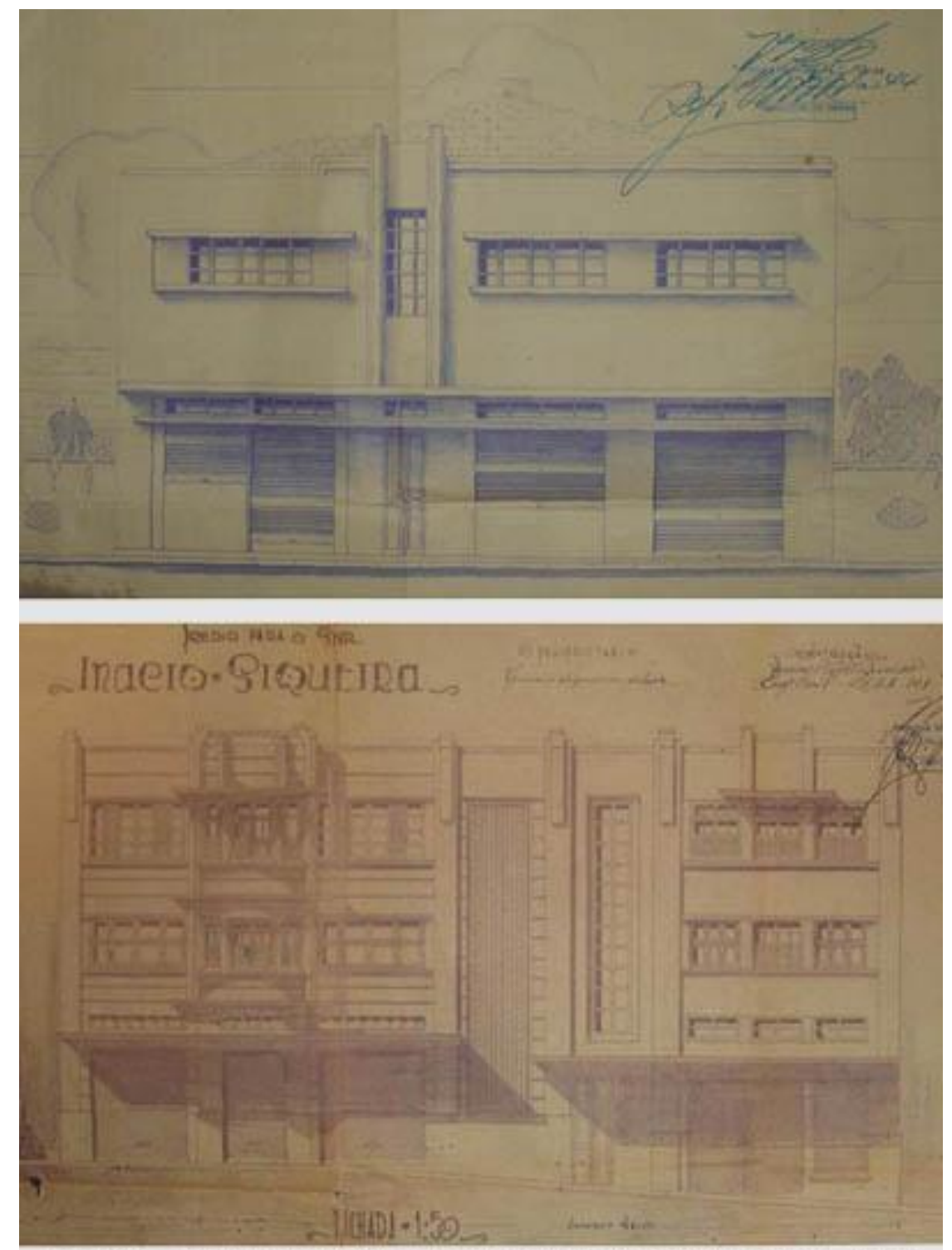

Figura 05: Sobrados construidos nas ruas centrais de Campina Grande. Acima, projeto para a rua Marquês do Herval, 1944. Propriedade de Júlio Ferreira. Abaixo, projeto para a esquina entre as ruas Cardoso Vieira e Venâncio Neiva, 1948. Propriedade de Inacio Siqueira Silver. Fonte: Arquivo Público Municipal de Campina Grande. 
A substituição da ornamentação profusa, típica do ecletismo, pela limpeza dos planos horizontais e verticais escalonados e em alto ou baixo relevo também trazia consigo uma nova estética: a do cimento. No México, por exemplo, as indústrias do material, segundo Alanis (1997, p. 29) "criaram uma imagem publicitária de que o uso do cimento desembocaria em obras modernas" Lá, o art déco

[...] procurou não apenas o uso extensivo de estruturas de sustentação à base de concreto armado (decisão tomada mais por motivos de economia e facilidade construtiva), mas também, externamente, a manifestação plástica do uso do cimento. (ALANIS, 1997, p. 29). (16).

Ademais, a eliminação da ornamentação profusa e a busca por formas limpas e geométricas possivelmente caminharam junto com os interesses de mercado: diminuíram o tempo do projeto, baixaram custos e aumentaram a velocidade de execução das construções, com o emprego de mão-de-obra menos qualificada do que a dos antigos mestres que aplicavam os ornamentos. O movimento higienista fez coro com essa lógica da simplicidade formal, bradando que os ornamentos, não só em fachadas, mas em móveis, paredes internas e utensílios cotidianos, acumulavam poeira e dificultavam a limpeza do espaço doméstico. Não é à toa que a produção de habitação higiênica de aluguel para a média e baixa renda fez uso intensivo da estética art déco, padronizando conjuntos inteiros de fachadas (figuras 03 e 06). Os prédios do serviço de saneamento de Campina Grande, projetados e construídos pelo Escritório Saturnino de Brito, seguiram pelo mesmo caminho. 

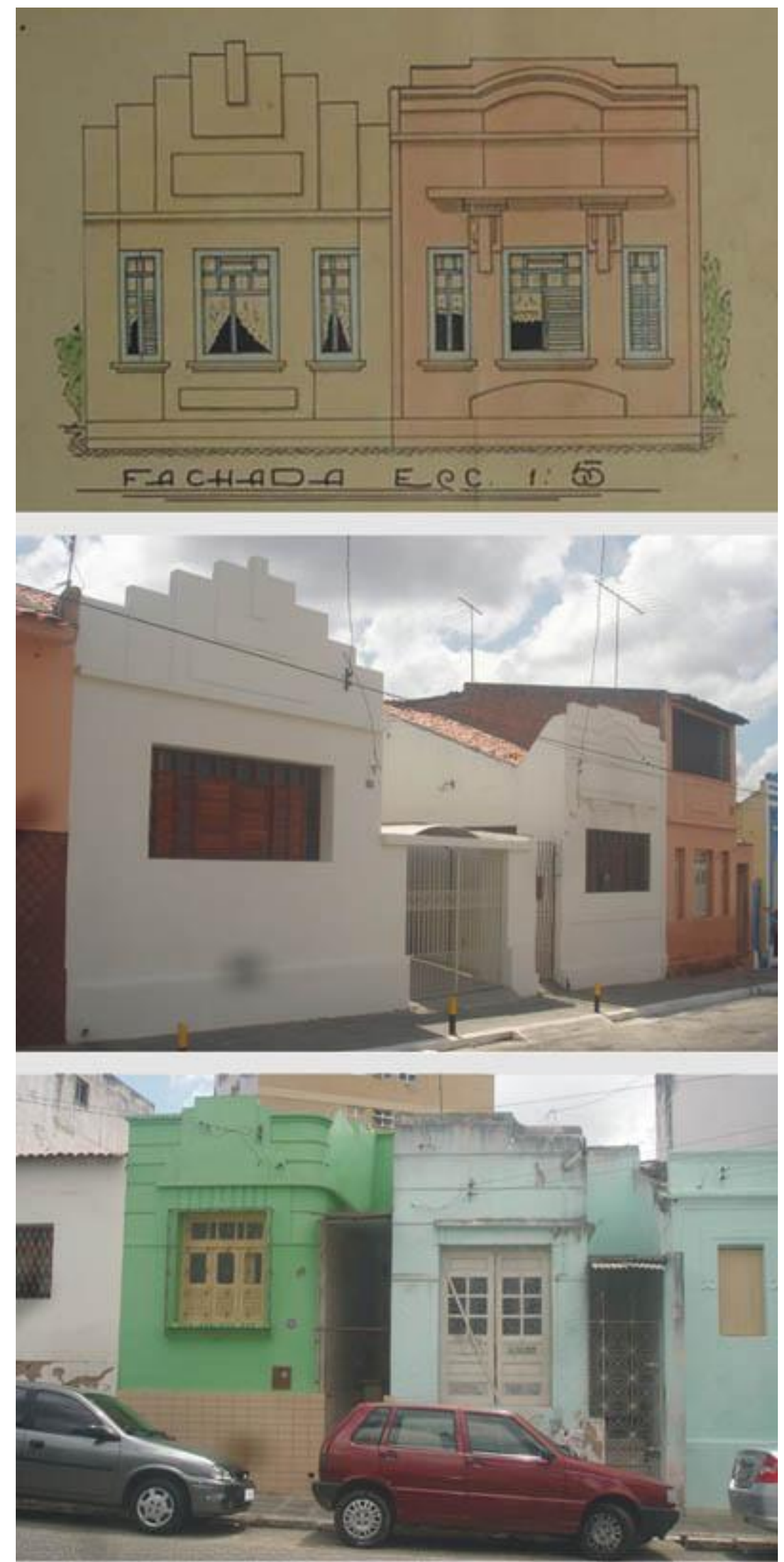

Figura 06: Acima e ao centro, conjunto de casas na rua Otacilio de Albuquerque, 1934. Abaixo, casas na rua Major Juvino do Ó. Fontes: Arquivo Público Municipal de Campina Grande. Fotos do autor. 
O uso das mesmas técnicas construtivas, aliadas a uma produção que esteve majoritariamente nas mãos dos poucos projetistas estabelecidos na cidade, talvez explique a certa uniformidade entre os edifícios art déco de Campina Grande. Os arquitetos Isaac Soares e Josué Barbosa projetaram grande parte dos prédios campinenses das décadas de 1930 e 1940. Rossi (1994) chegou a batizar essa realização campinense de Art Déco Sertanejo, atribuindo a ela características regionais que a distinguiriam do resto da produção nacional. Lembrando da grande importância do seu trabalho em prol do reconhecimento, do restauro e da conservação de tais edifícios, não acreditamos que o art déco de Campina Grande se diferencie do art déco desenvolvido em cidades como Goiânia, Rio de Janeiro, Belo Horizonte, São Paulo ou nos diversos municípios da região sul do Brasil.

Em meio a esse processo, também houve a construção de edifícios que perderam qualquer referência decorativa, sem listras, baixos e altos relevos nem planos escalonados. Se o art déco pode ser definido como uma arquitetura que se apropriou de temáticas distintas em busca de uma estética moderna de cunho decorativo, esses edifícios não podem ser classificados de tal forma. Para Somekh (1997, p.117), o que aconteceu com essa arquitetura foi a perda de ornamentação, decorrente do fim de mão-de-obra especializada disponível para conseguir o resultado próprio do ecletismo e, ao mesmo tempo, a necessidade de maior aumento de produtividade. Analogamente ao urbanismo, a arquitetura passou "pela necessidade de modernização e do aumento da produtividade" (SOMEKH, 1997, p. 117). Segundo a autora, temos, nesse caso, edifícios não-decorados. "É, portanto, uma arquitetura non déco, que perde a ornamentação do ecletismo" (SOMEKH, 1990, p. 117), ou até mesmo o apelo decorativo do art déco, como no nosso caso.

Da mesma forma, definir o novo edifício dos Correios e Telégrafos (1950) e o Grande Hotel (1936-1942) apenas como art déco é reduzir a análise a seus poucos ornamentos de fachada (figura 07). Os dois foram construídos para atender a programas modernos, complexos e em escalas inéditas, e estavam imbuídos de conceitos como funcionalidade, eficiência e economia, lemas próprios de uma arquitetura racionalista que ganhou firme aplicação em obras públicas no Brasil dos anos 1930 (SEGAWA, 2002, p. 66). A adoção de tais conceitos fez parte das 
políticas de modernização administrativa empreendidas pelo governo Vargas, seguidas por seus representantes estaduais e municipais, como foi o caso, na Paraíba, dos programas para a construção de escolas e prédios públicos empreendidos pelo interventor Argemiro de Figueiredo, no âmbito da Diretoria de Viação e Obras Públicas do Estado (DVOP) (17). O edifício dos Correios de 1950, assim como o de 1933, fez parte do plano nacional de normalização arquitetônica estabelecido pelo Departamento de Correios e Telégrafos, cujo intuito era o de otimizar a infraestrutura das agências postais do país (18). Já o Grande Hotel, com seu jogo de volumes, limpeza formal, exploração do concreto armado e integração espacial entre os cinco pavimentos através de um grande vazio circular central, aproximava-se mais de uma modernidade que tentava romper com o comum das construções da época. Vale lembrar que, tanto o Grande Hotel quanto o novo prédio da Prefeitura Municipal, introduziram o elevador de forma pioneira nos edifícios da cidade, símbolo máximo de um modelo urbano que pregava a verticalização como sinônimo de progresso e de reprodução do solo citadino. 

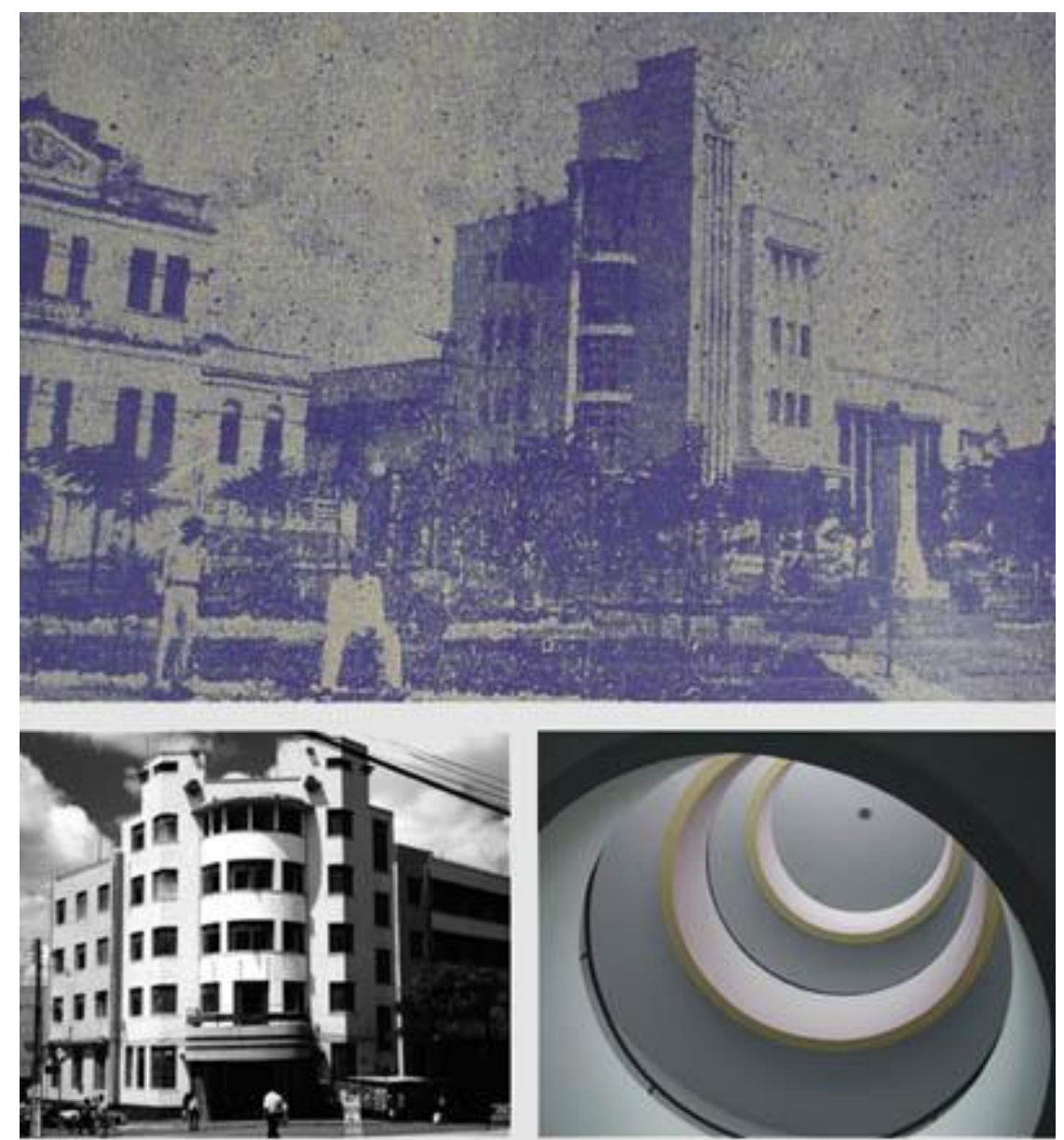

Figura 07: Acima, novo edificio dos Correios e Telégrafos: "Campina Grande moderniza-se [..]. A nossa terra ganhou mais um bonito edificio, seguindo o seu acelerado ritmo de modernização urbanistica". Abaixo, Grande Hotel. Em pesquisa recente, a arquiteta Adriana Almeida atribui o projeto ao arquiteto francès Georges Munier. Fontes: Revista Manaira, No.65, dez. 1950. Fotos do autor.

\section{Neocolonial, missões e outras manifestações}

Paralelamente ao art déco, aos resquícios de um ecletismo historicista e às primeiras aparições de uma arquitetura influenciada pelo racionalismo europeu (19), foi comum a construção de edifícios que faziam referência aos chalés suíços, à arquitetura das missões espanholas que colonizaram o sudoeste dos Estados Unidos e às nossas raízes coloniais portuguesas. Vinculadas à estética do pitoresco e aos movimentos nacionalistas irrompidos em países europeus e americanos nas primeiras décadas dos novecentos, incluindo o Brasil, essas arquiteturas estavam imbuídas de um sentimento de nostalgia, de romantismo, de culto a um passado pré-industrial, camponês, anterior à ruptura entre o homem e a natureza advinda com as dimensões e com o ambiente construído da cidade moderna (20). 
O uso dessas linguagens nos edifícios da cidade se deu de maneira híbrida, num procedimento compositivo próximo do ecletismo, longe das ideologias como as que fundaram o movimento neocolonial no Brasil. Tal manifestação, inaugurada pelo engenheiro português Ricardo Severo, seguida e defendida por José Mariano Filho, Mário de Andrade e Lúcio Costa, preconizava, naquele começo do século XX, que a modernização da arquitetura brasileira se daria pela valorização das artes tradicionais do país, entendidas como de origem portuguesa (SEGAWA, 2002, p. 35). De cunho altamente nacionalista, esse debate circulou na imprensa paraibana dos anos 1930. Em artigo publicado no jornal oficial $A$ União, em março de 1932, Josa Magalhães defendeu "que a nossa arquitetura deve refletir um caráter nacional" e definiu o neocolonial como o "estilo que nos convém" (MAGALHÃES apud SOUSA, 2001, p. 250).

Já em julho de 1935, o mesmo jornal publicou um artigo assinado por Azevêdo Amaral (21). O texto trazia considerações sobre a "Architectura e Urbanismo" brasileiros, tecia comentários sobre o plano Agache, sobre as reformas de Pereira Passos e, mais adiante, relatava o conteúdo da palestra proferida pelo arquiteto português Raul Lino na Escola Nacional de Belas Artes do Rio de Janeiro. Segundo Amaral (1935), Lino "concitou os seus collegas brasileiros a procurar desenvolver um estylo creado sob os imperativos esthéticos da nossa ambiencia e da nossa tradição".

Acerca desse ultimo ponto convem observar que o sr. Raul Lino não communga as idéias de uma escola que tem pleiteado entre nós formas architectonicas calcadas em imitação mecanica de moldes pertencentes a periodos passados do nosso desenvolvimento historico. $\mathrm{O}$ architecto português é um grande artista no sentido profundo da expressão e mais não é preciso accrescentar, para que se comprehenda que ao seu espirito repugna a tendencia a uma arte que não corresponda ás caracteristicas do dinamismo da vida contemporânea. (AMARAL, 1935)

Tomado pelo espírito nacionalista corrente em seu país, "a busca de Lino (22) por uma linguagem arquitetônica genuinamente portuguesa foi profunda e distinta de pastiches gratuitos" (MASCARO et al, 2007). E os mesmos autores afirmam: 
$\mathrm{O}$ arquiteto recomendava que as construções deveriam manter uma uniformidade dada pela linguagem nacional própria da época corrente, mas que a autenticidade não era alcançada através da simples 'colagem' de características tradicionais.

No Brasil, embora muito vinculada à década 1920, a produção neocolonial teve larga difusão entre os anos 1930 e 1940. Porém, "a força instauradora contida em seus postulados foi fenecendo em imitações inconsistentes e destituídas da carga ideológica formulada por seus idealizadores" (SEGAWA, 2002, p. 38).

Em Campina Grande, referências do neocolonial, do missões e até dos chalés poderiam estar juntas em um só edifício. Frontões com volutas, falsos beirais (soltos na composição geral das fachadas ou contornando as platibandas), torreões, colunas retorcidas, painéis de azulejos, varandas laterais com telhados apoiados em mãos-francesas, telhados com grandes inclinações, chaminés, terraços e varandas em arco, janelas protegidas por grades de ferro artisticamente trabalhadas, lampiões de ferro pendurados no exterior, altos relevos em cimento criando falsas estruturas de madeira nas fachadas foram alguns dos elementos formais que compuseram essa produção local (figuras 08 e 09). 

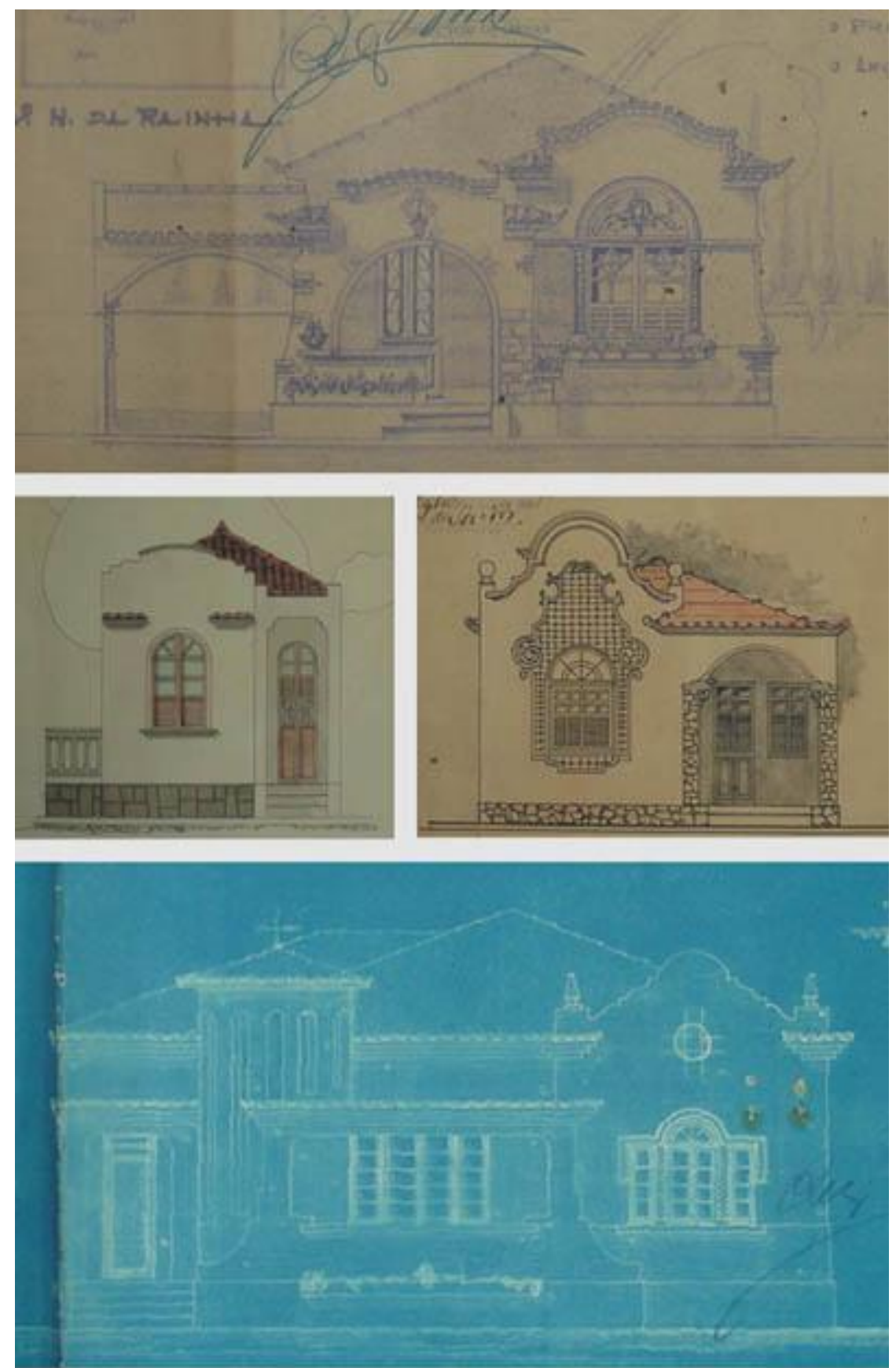

Figura 08: Acima, residência para Alexandrino Cavalcanti Belo. Rua Vila Nova da Rainha, 1946. Projeto do arquiteto licenciado Josué Barbosa. Ao centro: à esquerda, residência para Maria das Graças de Azevedo Cruz. Rua Octacílio de Albuquerque, 1934. Á direita, residência para Antônio Cavalcanti. Rua Tiradentes, 1935. Projeto do desenhista Antônio Henriques. Abaixo, Residência para Raimundo Vianna. Rua Nilo Peçanha, 1945. Projeto do arquiteto Clodoaldo Gouvêa. Fonte: Arquivo Público Municipal de Campina Grande. 

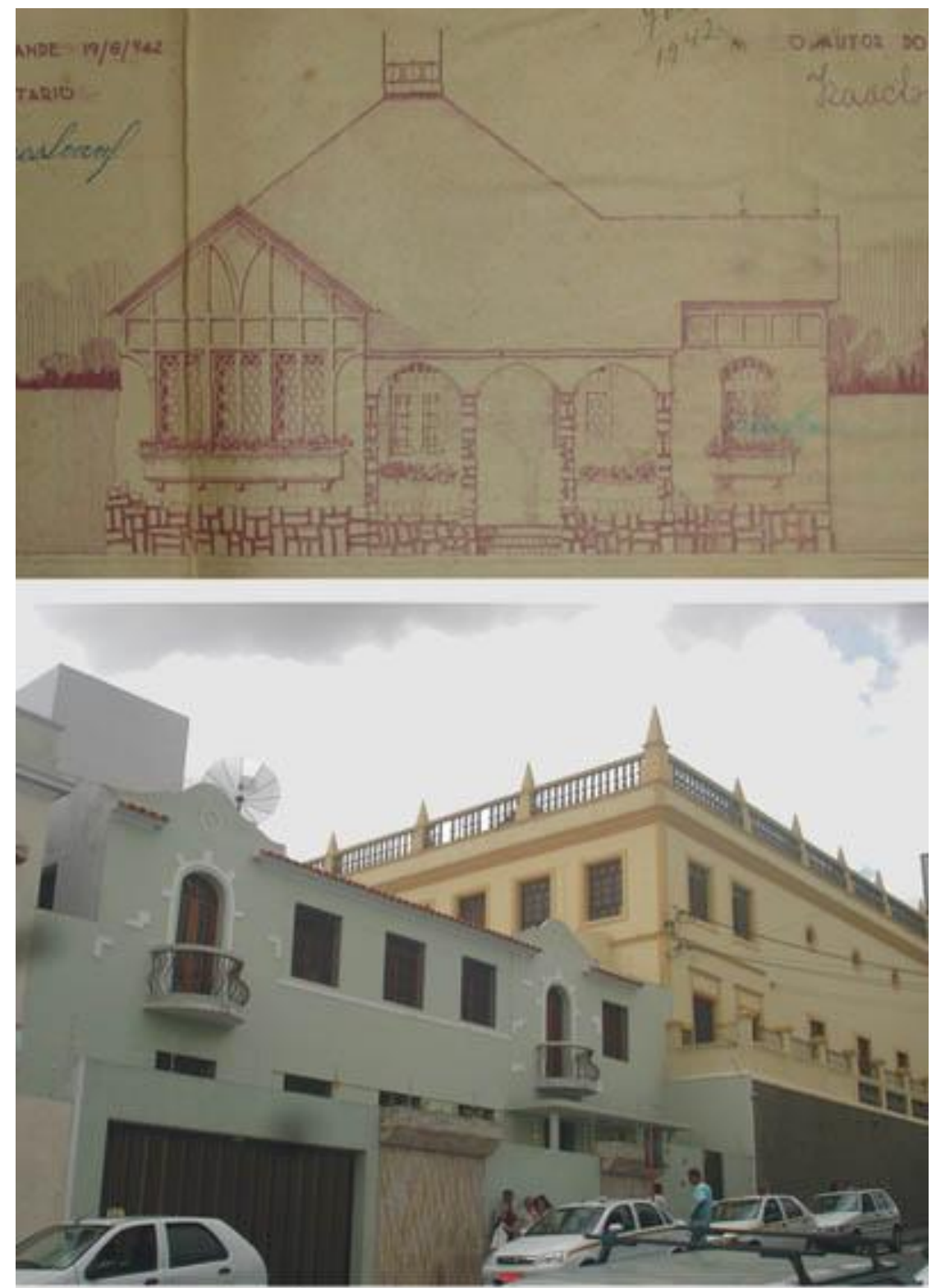

Figura 09: Acima, residência para Fleury Gomes Soares. Avenida Getúlio Vargas, 1942. Projeto do arquiteto licenciado Isaac Soares. Abaixo, Casa Paroquial da Catedral de Nossa Senhora da Conceição. Fontes: Arquivo Público Municipal de Campina Grande. Foto do autor.

Tais manifestações românticas estiveram quase sempre vinculadas à arquitetura residencial, principalmente dos subúrbios de lotes extensos. Difundidas por arquitetos, desenhistas e engenheiros, ou por publicações nacionais à venda em lojas da cidade (23), como a revista $A$ Casa, foram mais comuns entre as classes médias e ricas, proprietárias de residências soltas dos limites dos terrenos. A difusão por esses meios foi relatada em entrevista concedida pelo engenheiro e arquiteto Geraldino Pereira Duda (nascido em 1935) ao jornal local Diário da Borborema, de 28 de agosto de 1988. Duda ficou conhecido na cidade por seus projetos de 
orientação modernista, tendo, anteriormente, trabalhado no escritório do arquiteto licenciado Josué Barbosa. Na entrevista, ele lembrou que, antes da maior aceitação da arquitetura moderna no município, a partir dos anos 1950, as preferências dos clientes para a construção de residências eram pelos "estilos ingleses, espanhóis e portugueses" difundidos pelas publicações nacionais (DINOÁ, 1988). Em alguns casos, os clientes pediam para que fossem feitas cópias exatas dos projetos divulgados nas revistas. Ruas como João da Mata, Desembargador Trindade, Miguel Couto (depois Getúlio Vargas) e logradouros do bairro da Prata eram alguns dos lugares que ostentavam essas residências de "gosto estético, contrastando com a maior parte dos casarões pesados, sem luz direta, nem condições higiênicas, existentes na parte central e primitiva da cidade" (24).

Não foi à toa que se tornaram mais frequentes nessas áreas periféricas do núcleo urbano, longe dos barulhos, dos odores e das misturas da região central. Aí, as grandes dimensões dos lotes permitiram o afastamento da rua e dos vizinhos, garantindo maior privacidade para seus moradores. Possibilitaram, também, a construção de lagos e o cultivo de jardins, hortas e pomares, estabelecendo uma relação entre o homem e a natureza difícil de ser conquistada nos lotes de áreas limitadas presentes nas principais ruas do centro campinense. O sossego que se desejava criar nessas regiões ficou evidente em legislações da época. Em setembro de 1940, a administração do prefeito Vergniaud Wanderley aprovou decreto que isentou do imposto predial (a décima urbana) "os prédios construídos na Avenida João da Mata, orçados em importancia superior á vinte contos de reis (20:000\$000), pelo espaço de cinco (5) anos e que tiverem um só pavimento" (25). Ao contrário do estímulo fiscal concedido para quem verticalizasse os edifícios construídos ou reformados nas principais ruas do centro, incentivando o adensamento urbano e os usos comerciais e de serviço, almejava-se que os subúrbios se firmassem como zonas residenciais pouco adensadas, "tranquilas" para as classes abastadas e proprietárias das mais novas máquinas de deslocamento: o automóvel.

O avanço das técnicas construtivas, a busca por ar e luz no interior das construções, as recentes noções de privacidade, a instalação das redes mecanizadas de abastecimento de água e coleta dos esgotos redefiniram o panorama arquitetônico local, seguindo os mesmos limites e indefinições da modernização da arquitetura 
brasileira naquelas primeiras décadas do século 20. Seja em expressões julgadas como eruditas ou populares, projetadas por arquitetos formados pela ENBA ou por pedreiros locais, erguidas com técnicas construtivas inovadoras ou tradicionais, subvertendo ou conservando antigas formas de organização espacial, o que se queria era espelhar os novos tempos e ritmos vividos, nem que fosse apenas na fachada.

As apropriações e as traduções das várias posturas e linhas de pensamento projetuais em circulação na época deram origem a um panorama arquitetônico híbrido, diversificado e contraditório, próprio do turbilhão, das incertezas e das velozes transformações que caracterizam a modernidade e os seus agentes (26). Como recorte e ressonância de debates e realizações em âmbitos nacional e internacional, o conjunto arquitetônico edificado em Campina Grande ao longo dos 1930 e 1940 rompeu com as limitações e com as ditas letargia e monotonia do seu aspecto construtivo dos finais dos oitocentos e começo dos novecentos. Pelo menos nos espaços principais e fotografados, criou-se a desejada imagem de modernidade.

\section{Notas}

(1) Este artigo é uma versão revisada de parte do capítulo 3 da dissertação de mestrado intitulada "Quem te vê não te conhece mais: arquitetura e cidade de Campina Grande em transformação (1930-1950)", defendida em agosto de 2008 no Programa de Pós-Graduação da EESC-USP, sob a orientação da Prof. Dra. Maria Ângela Bortolucci e com o auxílio da FAPESP (processo №. 05/52920-0). Agradeço a leitura e pertinentes comentários da Profa. Ms. Mariana Bonates, do Curso de Arquitetura e Urbanismo da Universidade Federal de Campina Grande.

(2) Incluindo zonas urbana, rural e distritos. Cf. Câmara (1947) e dados do IBGE (disponíveis em www.ibge.gov.br, Estatísticas do século XX).

(3) Cf. Fabris (1987), Reis Filho (1970), Lemos (1999) e Segawa (2002).

(4) Para o art déco em Goiânia, ver Coelho (1997) e Unes (2001).

(5) Para a difusão do art déco na América Latina, ver publicação do Centro de Arquitetura e Urbanismo do Rio de Janeiro (1997) e Campos (1996 e 2003).

(6) Esta obra, cujo projeto padronizado foi executado em diversas cidades do interior paraibano (como Areia e Guarabira), fez parte do plano nacional de normalização arquitetônica oficial estabelecida pelo então Departamento dos Correios e Telégrafos (PEREIRA, 1999). Seu objetivo era modernizar a estrutura física da 
repartição frente às novas necessidades surgidas com multiplicação da rede postal e telegráfica pelo país, fruto da política varguista de integração do território brasileiro através de investimentos nos meios de comunicação estatais. Sobre o assunto, ver Pereira (1999), Segawa (2002, p.52-76) e Trajano Filho (2003, p.28).

(7) Arquitetos licenciados eram profissionais sem formação acadêmica, mas que recebiam, mediante habilidade comprovada, a autorização dos conselhos regionais de engenharia e arquitetura para atuar legalmente na profissão.

(8) Até o momento, a pesquisa não localizou maiores informações sobre a formação dos arquitetos Isaac Soares e Josué Barbosa.

(9) Não localizamos maiores informações sobre esses profissionais. As grafias aqui apresentadas, inclusive com abreviações, estão de acordo com as escritas encontradas nos projetos apresentados à Diretoria de Obras de Campina Grande.

(10) Ver Trajano Filho (2003).

(11) Além dessas duas fontes de influência, o Art Déco se referenciou em movimentos como Arts and Crafts, Weiner Werstätte, Deutscher Werkbund, Futurismo/Vorticismo, Cubismo, Der Blane Reiter e De Stijl (Neoplasticismo) e em eventos do pós primeira guerra, como o Ballets Russes, o cinema, o jazz norteamericano, a construção de transatlânticos, as culturas primitivas da África e da América Pré-colombiana (CAMPOS, 1996, p.22-32). Sobre o assunto, ver também Pinheiro (1997, p.205-206).

(12) Cf. Conde e Almada (2000, p.9) e Pinheiro (1997, p.205). Para a associação entre o art déco e o cinema, ver textos de José Carlos Avellar, Leonardo Barci Castriota e Renato da Gama-Rosa Costa na publicação do Centro de Arquitetura e Urbanismo do Rio de Janeiro (1997).

(13) Cf. Campos (1996, p.18), Conde e Almada (2000, p.11) e Pinheiro (1997, p.206).

(14) O texto foi assinado por Raymundo de Moraes.

(15) Cf. Conde e Almada (2000, p.15).

(16) Sobre a associação entre o art déco e as formas provenientes do cimento e do concreto armando, ver texto sobre Auguste Perret em Segawa (2002, p.59).

(17) Para a ação da DVOP na Paraíba dos anos 1930, ver Trajano Filho (2003).

(18) Sobre o assunto, ver Pereira (1999), Segawa (2002, p.52-76) e Trajano Filho (2003, p.28).

(19) Chamada de Protomoderna por Naslavsky (1998) ou de Modernidade Pragmática por Segawa (2002).

(20) Para maiores informações, definições e conceitos sobre essa arquitetura de caráter pitoresco, ver Pinheiro e D’agostinho (2004). A tradição pitoresca que permeou essa produção influenciou movimentos como o Arts and 
Crafts, de Jonh Ruskin, as cidades-jardins de Ebenezer Howard e os ideários de Camillo Sitte. Para uma síntese sobre esses assuntos e seus vínculos com a tradição pitoresca, ver Andrade (1998) e Porto (2005).

(21) O texto era uma cópia de artigo publicado pela Companhia Editora Nacional. Para maiores informações sobre Azevedo Amaral, ver Sousa (2005).

(22) Segundo Mascaro (et al, 2007), Raul Lino "estudou na Inglaterra e na Alemanha, contrariando a tendência do momento mais voltada para a cultura francesa, onde recebeu forte influência do Romantismo e tomou contacto com o movimento Arts and Crafts".

(23) A Casa Brasil, que ficava na rua Cardoso Vieira, anunciava a venda da revista $A$ Casa em anúncios publicados em jornais da cidade (JORNAES..., 1937).

(24) Relatório da administração Vergniaud Wanderley apresentado à Câmara Municipal de Campina Grande. Referente ao período de 1 de janeiro a 31 de dezembro de 1936. Disponível no Arquivo Público Municipal de Campina Grande.

(25) Solicitação de isenção de imposto (décima urbana) sobre imóvel. Avenida João da Mata. Proprietário Maria do Carmo Moura Leite. 1941. (Arquivo Público Municipal de Campina Grande).

(26) Cf. Berman (1986).

\section{Referências bibliográficas}

ALANIS, E. X. A. A Arquitetura Déco no México: uma proposta de vanguarda em tempos de modernidade. In: CENTRO DE ARQUITETURA E URBANISMO DO RIO DE JANEIRO. Art Déco na América Latina. Rio de Janeiro: Prefeitura Municipal do Rio de Janeiro/ Solar Grandjean de Montigny, 1997. p. 28-35.

AMARAL, A. Architectura e urbanismo. Jornal A União, João Pessoa, 30 jul. 1935.

ANDRADE, C. R. M. Barry Parker: um arquiteto inglês na cidade de São Paulo. Tese (Doutorado)-Faculdade de Arquitetura e Urbanismo, Universidade de São Paulo, São Paulo, 1998.

ARANHA, G. B. Seduções do moderno na Parahyba do norte: trem de ferro, luz elétrica e outras conquistas materiais simbólicas (1880-1925). In: Ó, A. A. et al. Paraíba no império e na república: estudos de história social e cultural. 2. ed. João Pessoa: Ideia, 2005.

Trem, modernidade e imaginário na Paraíba e região: tramas político-econômicas e práticas culturais (1880-1925). Tese (Doutorado)-Instituto de Filosofia e Ciências Humanas, Universidade Estadual de Campinas, Campinas, 2001.

BERMAN, M. Tudo o que é sólido desmancha no ar: a aventura da modernidade. São Paulo: Companhia das Letras, 1986. 
BRESLER, H. O Art Décoratif moderno na França. In: CENTRO DE ARQUITETURA E URBANISMO DO RIO DE JANEIRO. Art Déco na América Latina. Rio de Janeiro: Prefeitura Municipal do Rio de Janeiro/ Solar Grandjean de Montigny, 1997. p. 10-17.

CÂMARA, E. Os alicerces de Campina Grande. Campina Grande: Livraria Moderna, 1943. Reimpressão de 1999 pela Editora Caravela.

Continuação. Revista Manaíra, Campina Grande, n. 65, dez. 1950.

Datas campinenses. João Pessoa: Departamento de publicidade, 1947. Reimpressão de 1998 pela Editora Caravela.

CAMPOS, V. J. B. Art déco na arquitetura paulistana: uma outra face do moderno. Dissertação (Mestrado)Faculdade de Arquitetura e Urbanismo, Universidade de São Paulo, São Paulo, 1996.

$O$ art déco e a construção do imaginário moderno: um estudo de linguagem arquitetônica. Tese (Doutorado)-Faculdade de Arquitetura e Urbanismo, Universidade de São Paulo, São Paulo, 2003.

CAPEL. H. Caminos de modernización en la Europa ultramarina. In: FERREIRA, A. L.; DANTAS, G. (Orgs.). Surge et ambula: a construção de uma cidade moderna. Natal, 1890-1940. Natal: EDUFRN, 2006.

CENTRO DE ARQUITETURA E URBANISMO DO RIO DE JANEIRO. Art déco na América Latina. Rio de Janeiro: Prefeitura Municipal do Rio de Janeiro/ Solar Grandjean de Montigny, 1997.

COELHO, G. N. A modernidade do art déco na construção de Goiânia. Goiânia: Ed. do Autor, 1997.

CONDE, L. P.; ALMADA, M. Panorama do Art Déco na arquitetura e no urbanismo do Rio de Janeiro. In: CZAJKOWSKI, J. (Org.). Guia da arquitetura Art Déco no Rio de Janeiro. 3. ed. Rio de Janeiro: Prefeitura Municipal do Rio de Janeiro/ Casa da Palavra, 2000.

CORREIA, T. B. Art déco e indústria: Brasil, décadas de 1930 e 1940. Anais do Museu Paulista, São Paulo, v. 16, n. 2, p. 47-104, jul./dez. 2008.

DINOÁ, R. A arquitetura de Geraldino Duda. Jornal Diário da Borborema, Campina Grande, 28 ago. 1988.

FABRIS, A. (Org.). Ecletismo na arquitetura brasileira. São Paulo: Nobel/Edusp, 1987.

JORNAES e revistas. Jornal Voz da Borborema, Campina Grande, 28 jul. 1937.

LEMOS, C. A. C. A república ensina a morar (melhor). São Paulo: Hucitec, 1999.

MASCARO, L. P.; BORTOLUCCI, M. A.; LOURENÇO, J. M. Raul Lino: uma leitura dos projetos das "casas portuguesas". Artigo submetido à revista Oculum, out. 2007. 
NASLAVSKY, G. Modernidade arquitetônica no Recife: arte, técnica e arquitetura (1920-1950). Dissertação (Mestrado)-Faculdade de Arquitetura e Urbanismo, Universidade de São Paulo, São Paulo, 1998.

PEREIRA, M. S. Os correios e telégrafos no Brasil: um patrimônio histórico e arquitetônico. São Paulo: MSP/ Empresa Brasileira de Correios e Telégrafos, 1999.

PINHEIRO, M. L. B. Arquitetura residencial verticalizada em São Paulo nas décadas de 1930 e 1940. Anais do Museu Paulista, São Paulo, v. 16, n. 1, p. 109-149, jan./jun. 2008.

Moderno ou moderne? Questões sobre a arquitetura francesa no entreguerras. In: CENTRO DE ARQUITETURA E URBANISMO DO RIO DE JANEIRO. Art Déco na América Latina. Rio de Janeiro: Prefeitura Municipal do Rio de Janeiro/ Solar Grandjean de Montigny, 1997. p. 205-210.

PINHEIRO, M. L. B.; D'AGOSTINHO, M. H. S. A noção de pitoresco e o debate cultural das primeiras décadas do século XX no Brasil. Desígnio: revista de história da arquitetura e do urbanismo (FAUUSP). São Paulo: Annablume, n. 1, p. 119-128, mar. 2004.

PORTO, D. R. O Barreiro de Araxá: projetos para uma estância hidromineral em Minas Gerais. Dissertação (Mestrado)-Departamento de Arquitetura e Urbanismo da Escola de Engenharia de São Carlos, Universidade de São Paulo, São Carlos, 2005.

QUEIROZ, M. V. D. Quem te vê não te conhece mais: arquitetura e cidade de Campina Grande em transformação (1930-1950). Dissertação (Mestrado)-Programa de Pós-Graduação em Arquitetura e Urbanismo da Escola de Engenharia de São Carlos, Universidade de São Paulo. São Carlos, 2008.

REIS FILHO, N. G. Quadro da arquitetura no Brasil. São Paulo: Perspectiva, 1970.

ROSSI, L. M. Art Déco sertanejo. Design \& Interiores, São Paulo, n. 41, 1994.

SEGAWA, H. Arquiteturas no Brasil 1900-1990. 2. ed. São Paulo: EDUSP, 2002.

SOMEKH, N. A forma da utopia: o urbanismo modernizador de Prestes Maia. In: CENTRO DE ARQUITETURA E URBANISMO DO RIO DE JANEIRO. Art déco na América Latina. Rio de Janeiro: Prefeitura Municipal do Rio de Janeiro/ Solar Grandjean de Montigny, 1997. p. 114-118.

SOUSA, F. G. R. B. Cartografias e imagens da cidade: Campina Grande 1920-1945. Tese (Doutorado)Departamento de Historia do Instituto de Filosofia e Ciências Humanas, Universidade de Campinas, Campinas, 2001.

SOUSA, R. L. Os caminhos da modernidade em Azevedo Amaral. Sociedade e cultura, Goiânia, v. 8, n. 1, p. 7181, jan./jun, 2005.

TEIXEIRA, L. E. F. Art Déco ou a modernidade tranqüilizadora. In: A ARQUITETURA Art Déco em Lages/SC (Relatório de pesquisa) - Universidade do Planalto Catarinense/Universidade Federal de Santa Catarina. Florianópolis, 2003. 
TRAJANO FILHO, F. S. D.V.O.P.: arquitetura moderna, estado e modernização (Paraíba, década de 1930). Dissertação (Mestrado)-Departamento de Arquitetura e Urbanismo da Escola de Engenharia de São Carlos, Universidade de São Paulo, São Carlos, 2003.

UNES, W. Identidade art déco de Goiânia. Cotia, SP: Ateliê Editorial; Goiânia: Universidade Federal de Goiás, 2001.

\section{Créditos}

* Arquiteto e urbanista pela Universidade Federal da Paraíba (UFPB), mestre pelo Programa de Pós-Graduação em Arquitetura e Urbanismo da Escola de Engenharia de São Carlos, Universidade de São Paulo (PPGAUEESC-USP) e docente do curso de Arquitetura e Urbanismo da Universidade Federal de Campina Grande (UFCG).

e-mail: marcusvidanq@yahoo.com.br

artigo recebido em 02/2010

artigo aprovado em 04/2010 